Volume 10, Issue 6, November-December 2019, pp. 247-253, Article ID: IJM_10_06_024

Available online at http://iaeme.com/Home/issue/IJM?Volume $=10 \&$ Issue $=6$

Journal Impact Factor (2019): 9.6780 (Calculated by GISI) www.jifactor.com

ISSN Print: 0976-6502 and ISSN Online: 0976-6510

\title{
CONSEQUENCE OF PERCEIVING USERS OF DIGITAL BANKING (WITH REFERENCE TO PRIVATE BANKS IN CHENNAI)
}

\author{
R. Vimaladevi \\ Assistant Professor, Department of Commerce, VELS Institute of Science, \\ Technology and Advanced Studies, Chennai, Tamilnadu, India. \\ A. Meenakshi \\ Assistant Professor, Department of Commerce, VELS Institute of Science, \\ Technology and Advanced Studies, Chennai, Tamilnadu, India.

\section{Dr. S. Vennilaa Shree} \\ Professor, Department of Commerce, VELS Institute of Science, \\ Technology and Advanced Studies, Chennai, Tamilnadu, India.
}

\begin{abstract}
The paper explores to know a consequence of perceiving users of digital banking with reference to private banks in Chennai. The researcher specified this research through digital banking user in private banks in the city of Chennai. The researcher has collected the primary data through a questionnaire which is well-structured. The researcher has used a method of chances for collecting the data from 60 responders. The percentage analysis and rank correlation method are employed to examine the information. This research inferred that the customers are highly satisfied with digital banking services and usage levels of the customers are also high. Further, it recommended that banking need to improve the following aspects such as one-stop-shop for banking needs, transactions through a digital kiosk, voice command that assist computer illiterate people, interface that make unique customer and the first-time user can perform a transaction easily. Thus, it enables the banking industries to render better services and to retain a valuable customer. Through digital banking, each and every program had been digitized and each and every activity is undertaken through institutions of financial and their customers.
\end{abstract}

Keywords: Digital banking, user, customers, responders.

Cite this Article: R. Vimaladevi, A. Meenakshi, Dr. S. Vennilaa Shree, Consequence of Perceiving Users of Digital Banking (With Reference to Private Banks in Chennai), International Journal of Management (IJM), 10 (6), 2019, pp. 247-253.

$\mathrm{http}: / /$ iaeme.com/Home/issue/IJM?Volume $=10 \&$ Issue $=6$ 


\section{INTRODUCTION}

The introduction of internet facility in the earlier 90's foster rapid revolution and vibrant development in the banking sectors in India. The diversification from the conventional method of banking had opened up new vistas to increase profits of the bank and reduce the operating cost. The digitalization in banking sectors supports to extend their hand in another area of banking such as universal banking, investment banking, mortgage financing, and personal banking, etc. Digitalization banking initially identified as using ATM cards and credit cards. Later, the banking sectors create their own way of designing a website on their needs. It enhanced another kind of services such as opening new accounts using online, downloading the necessary forms, and also applying for online loans. Moreover, it adds up other forms of features such as bill payments, transfer of funds, income tax filing, opening recurring accounts and fixed deposit. It results in inevitable growth in the soundness of the funding system which facilitates to meet the global competition.

The modern era witnessed that many businesses like Amazon, Flipkart have existed with the support of digital banking. Internet banking helps the business to allow payments through online and other events like deposits, fund transfer, monthly statements. So, it helps the businessperson can take the instant decision in their business process. It is not only helpful for the business even it greatly helpful for the working people. Especially, it reduces the work burden of the working people and also it helps to cost-cutting and save time. The proliferation of smartphone usage opened a moderate way of a transaction comparing to usage of ATM machines. In futures, the banks have to face challenges to facilitate the demands of customers to associate salespersons with money through channels which are determined by customers. The demands of the customers fulfilled only through CRM or customer relationship management software. So, the CRM must be linked into a system of digital banking that enables banks to interconnect directly through the customers. These attempts to explore the perception of digital banking services, usage level and channels most preferred by the customer in Chennai.

\section{AIMS}

- Consequence of perceiving of the usage level of digital banking.

- Preference levels of adopting the channel.

- Absorption of satisfaction levels of digital banking users.

\section{FOCUS}

Convenience and time saving are an inevitable process for any field to sustain in the competitive market. Modernization put forth up gradation in digital banking from conventional banking services. The customers are recipients of digital banking services. Thus, there is an emergency to recognize the opinion of the customer's sensitivity to digital banking. The research helps to identify whether the customers are satisfied with digital banking facilities. It also helps to identify the level of satisfaction of customers on various aspects of digital banking, usage level, and their preferred channel. It helps the banking sector to know the opinion regarding digital banking which helps them to cater to the needs of customers.

\section{PROPOSED TARGET}

The research emphasis to examine customer satisfaction with regards to digital banking facilities rendered in private sector banks. It attempts to know about the usage level of digital banking, channel preferred most and also to identify the level of satisfaction among the various aspects. 


\section{METHODOLOGY}

In securing the most effective results from the present research a methodology has been framed. The data comprises of two vital parts such as primary and secondary. The primary data devoted to gathering opinion from customers of private banks. The researchers used a simple random sampling method for collecting data from 60 respondents. The percentage analysis, Rank correlation used to evaluate the data. The secondary data were collected from the dissertation, journals, and websites.

\section{LIMITATIONS}

- The number of responders restricted to 60 samples imposed by time and cost factors.

- The questionnaires had been dispersed to customers of the private banks.

- The duration of the project is limited to 3 months.

\section{EXAMINATION OF LITERATURE}

Digi et al. (2009) the researcher aimed to know about internet banking can bring sustainable competitive advantage in terms of market share rather more than profit-making. The results are retrieved from the report of world retail banking in the year 2009. This research inferred that an active user of online banking used 34\% transactions which is not more than an active user. However, these findings show the implementation of aggressive policy discourage the customers to visit branches.

Elizabeth Ujarura Kamutuezu (2016) this research set hypothesis the factors which influence the adoption of online banking. The researcher employed a non-probability sampling method. An SAQ had been employed to gather the information of the 50 users of online banking and 16 non-users from four banks. The research model derived from Fred Davis's Technology Acceptance Model in order to focus over variables of four beliefs of PU or perceived usefulness and PEOU, credibility and convenient. The result shows that PEOU and Convenient are key factors which influence the adoption of online banking in Namibia.

Grui Anton (2014) target to know about the influence of internet banking over the use of banking services in top 10 Ukrainian banks in Ukraine. The data collected from 9554 customers in the select banks. The data analyzed through regression tool. This research revealed that most younger people and customers with higher salaries have started to use internet services. Further, this proposal postulates certain facts that youth is more prone to adopt internet technologies with higher-income people more chances to maintain internet banking services, as its convenient low-cost remote transactions.

Isaeva et al. (2012) this research focused to know about the impact of internet banking on the use of banking services in the US. The information had been gathered from 75 banks in the US and examines the views of bankers that had been provided banking services via the internet. From this proposal, it is understood that the transaction costs had been reduced through online banking. These also raise both the customers and the customer base.

Lauri Piirainen (2017) explored the financial sector through digitalization and also to understand the key essentials in a successful change in management and its impacts on the financial and banking sector. The general view was conducted to employees of the Bank X and personalized feeling in changing management and digitalization of the banking industry. The researcher adopted both methods of qualitative and quantitative for empirical research. The findings show that change management was successful and satisfied feeling of changes in the employee of Bank X. This research suggested that the few key parts of development be taken into account in the employee of Bank $\mathrm{X}$ in order to improve the successfulness of their change management. 
Robert Ortstad (2017) attempt to know the role of digitalization in the banking sector has altered customers' preferences and demands in the Swedish bank. The intention of these researches is to examine in what way the digital focus affect the relationship among banks' and customers. This research has chosen a qualitative method that has been conducted through event research at a large Swedish bank. The data gathered in the research method to indicate that the relationship with customers has become less adapted and more mechanized. This also expresses that satisfaction had been raised between customers who oriented digitally. These increasing satisfactions are attained through the contribution of position in the bank.

Shiffu Abrol (2014) the researcher explored the title Impact of internet banking on customer satisfaction and business performance For this research, the primary information had been collected through questionnaire which is a type of structured from 144 respondents in Jammu city and secondary sources obtained from JIBC, JBF, JM or journal of marketing, electronic services or e-service journal, and dissimilar books. This research revealed that highly educated persons who are businessmen, workers and belong to higher income groups and younger are major users of internet banking. Further, the researcher recommends that banks must increase the training of their employees to handle customer issues effectively so that they bring confidence in the minds of customers about bank personnel and service package.

\section{DATA INTERPRETATION}

Table 1: Demographic Profile

\begin{tabular}{|l|l|c|c|}
\hline Variable & \multicolumn{1}{|c|}{ Variable categories } & No. & Percentage \\
\hline \multirow{4}{*}{ Gender } & Male & 36 & $60 \%$ \\
\cline { 2 - 4 } & Female & 24 & $40 \%$ \\
\hline \multirow{4}{*}{ Age-wise } & Less than 25 yrs & 18 & $30 \%$ \\
\cline { 2 - 4 } & $25-35$ yrs & 16 & $27 \%$ \\
\cline { 2 - 4 } & $36-50$ yrs & 18 & $30 \%$ \\
\cline { 2 - 4 } & Above 50 yrs & 8 & $13 \%$ \\
\hline \multirow{5}{*}{ Qualification } & SSLC & 10 & $3 \%$ \\
\cline { 2 - 4 } & HSLC & 24 & $17 \%$ \\
\cline { 2 - 4 } & UG & 24 & $40 \%$ \\
\cline { 2 - 4 } & PG & 10 & $17 \%$ \\
\hline \multirow{5}{*}{} & Less than 10,000 & 26 & $43 \%$ \\
\cline { 2 - 4 } & $10,000-20,000$ & 16 & $27 \%$ \\
\cline { 2 - 4 } & $20,000-40,000$ & 8 & $13 \%$ \\
\cline { 2 - 4 } & Above 40,000 & &
\end{tabular}

The above table shows that about $60 \%$ of the responders are Male and $40 \%$ of the responders are female from total responders of 60 . It indicates that male responders are moderately higher than the female. $30 \%$ of the responders are from the age group of underneath $25 \mathrm{yrs}, 27 \%$ of the responders are among the age group 25 and 35yrs, 30\% of the responders are among the age group of 36-50 yrs. and 13\% of the responders are the age group directly above $50 \mathrm{yrs.} \mathrm{3 \%}$ of the responders are SSLC, $17 \%$ of them are HSLC, $40 \%$ of the responders are undergraduates and $40 \%$ of the responders are postgraduates. It indicates that $17 \%$ of the responders are earning up to $10,000,43 \%$ of the responders are earning 10,000-20,000 monthly, $27 \%$ of the responders are earning $20,000-40,000$ and $13 \%$ of the responders are earning above 40,000 . 
Table 2: Usage Level of a Digital Bank During The Past 6 Month

\begin{tabular}{|l|c|c|}
\hline \multicolumn{1}{|c|}{ Usage level of digital bank } & Frequency & Percentage \\
\hline Never & 4 & $6 \%$ \\
\hline Once a month & 18 & $30 \%$ \\
\hline Two or three times per month & 12 & $20 \%$ \\
\hline Once or twice a week & 10 & $17 \%$ \\
\hline Three or more times per week & 16 & $27 \%$ \\
\hline
\end{tabular}

The above table shows that $6 \%$ of the total responders are not using digital bank last 6 months, $30 \%$ of responders are using once in a month during the 6 months, about $20 \%$ of responders are using two or three times a month, $17 \%$ of responders are using biweekly and $27 \%$ of responders are using three or more times per week. It indicates that most of them are using digital banking.

Table 3: Channels Preferred Most by The Digital User

\begin{tabular}{|l|c|c|}
\hline \multicolumn{1}{|c|}{ Channels } & Frequency & Percentage \\
\hline Online / internet banking & 38 & $63 \%$ \\
\hline Phone banking & 8 & $13 \%$ \\
\hline Smartphone applications & 10 & $17 \%$ \\
\hline Customer service representation & 4 & $7 \%$ \\
\hline
\end{tabular}

The table shows that $63 \%$ of them are employing online or internet banking, $13 \%$ of them are employing mobile banking, $17 \%$ of them are employing Smartphone or tablet applications and $7 \%$ of the respondents are using customer service representation. It reveals that online banking is preferred most by the digital user followed by phone banking, smartphone applications and customer services representation.

Table 4: Satisfaction Level of Digital Banking User

\begin{tabular}{|l|c|c|c|c|c|c|c|}
\hline \multicolumn{1}{|c|}{ Factors } & $\begin{array}{c}\text { Stron } \\
\text { gly } \\
\text { agree }\end{array}$ & $\begin{array}{c}\text { agr } \\
\text { ee }\end{array}$ & Neutral & Disagree & SDA & W.A & Rank \\
\hline $\begin{array}{l}\text { I believe that the } \\
\text { digital bank interface } \\
\text { is customized to my } \\
\text { need }\end{array}$ & 30 & 12 & 18 & 0 & 0 & 16.8 & 2 \\
\hline $\begin{array}{l}\text { The interface makes } \\
\text { me feel that I am a } \\
\text { unique customer }\end{array}$ & 20 & 10 & 20 & 8 & 2 & 14.53 & 8 \\
\hline $\begin{array}{l}\text { Interface responds } \\
\text { correspondingly to the } \\
\text { requests I enter }\end{array}$ & 34 & 8 & 12 & 4 & 2 & 16.53 & 3 \\
\hline $\begin{array}{l}\text { Responds request } \\
\text { quickly }\end{array}$ & 24 & 18 & 16 & 2 & 0 & 16.26 & 5 \\
\hline $\begin{array}{l}\text { A first-time user can } \\
\text { perform a transaction } \\
\text { easily }\end{array}$ & 18 & 6 & 18 & 14 & 4 & 13.33 & 9 \\
\hline $\begin{array}{l}\text { Interface provides } \\
\text { instructions in a user- } \\
\text { friendly way }\end{array}$ & 26 & 18 & 14 & 2 & 0 & 16.53 & 3 \\
\hline Very convenient & 28 & 16 & 16 & 0 & 0 & 16.8 & 2 \\
\hline $\begin{array}{l}\text { One-stop shop for } \\
\text { banking needs }\end{array}$ & 28 & 10 & 16 & 6 & 0 & 16.00 & 6 \\
\hline Attractive & 32 & 8 & 16 & 2 & 2 & 16.4 & 4 \\
\hline
\end{tabular}




\begin{tabular}{|l|c|c|c|c|c|c|c|}
\hline $\begin{array}{l}\text { Voice command that } \\
\text { assist computer } \\
\text { illiterate people }\end{array}$ & 16 & 8 & 22 & 10 & 4 & 13.46 & 8 \\
\hline Comfortable & 32 & 16 & 12 & 0 & 0 & 17.33 & 1 \\
\hline $\begin{array}{l}\text { Transactions through a } \\
\text { digital kiosk is fun }\end{array}$ & 24 & 14 & 14 & 2 & 6 & 15.20 & 7 \\
\hline
\end{tabular}

Table 4 shows the satisfaction level of digital banking user with following aspects, weighted average value (17.33) and (16.8) shows most of the responders are comfortable and convenient with the digital banking services, so, it is placed the first rank and second rank followed by user-friendly, attractive, respond quickly, digital bank user shows lesser response on the following aspects such as one-stop-shop for banking needs, Transactions through a digital kiosk is fun, so it positioned with six and seventh place followed by voice command that assists computer, illiterate people, The interface makes me feel that I am a unique customer and the first-time user can perform a transaction easily. So, it reveals that digital banking users had been satisfied highly through digital banking services.

\section{FINDINGS}

- About $60 \%$ of responders are Male and $40 \%$ responders are female from total respondents of 60

- $40 \%$ of responders are undergraduates and $40 \%$ of responders are postgraduates. It indicates that the responders are mostly graduates.

- $43 \%$ of the responders are earns $10,000-20,000$ monthly, $27 \%$ of the responders are earns $20,000-40,000$ and $13 \%$ of the responders are earns above 40,000 . It shows the most of them are earns directly above 10,000 .

- From the total responders, only $6 \%$ of them have not used digital banking during the last 6 months. So, it indicates that the usage level of digital banking is high among the customer.

- About $63 \%$ of the responders said the online /internet banking services are the most preferred channel among the various channels.

- Weight average value (17.33) and (16.8) indicate that the customers are feeling comfortable and convenient with the digital banking services among the various aspects. So, it is positioned with the first and second rank.

\section{CONCLUSION}

It concludes the customers are highly satisfied with digital banking services and usage levels of the customers are also high. Banking sectors have to concentrate to improve the level of satisfaction on the following aspects such as one-stop-shop for banking needs, transactions through a digital kiosk, voice command that assist computer illiterate people, interface that make unique customer and the first-time user can perform a transaction easily. Thus, it enables the banking industries to render better services and to retain a valuable customer.

\section{REFERENCES}

[1] Driga, Imola, Dorina Nita, and Codruța Dura, “Aspects Regarding Internet Banking Servies in Romania", Annals of the University of Petrosani, Economics, 9(3), 2009, p. 239-248

[2] Elizabeth Ujarura Kamutuezu, "The Adoption of Digital Banking in Namibia", Dissertation, Amity Centre for E-learning: Amity University, Noida, 2016

[3] Sahadeb Sukla Das. A Study of Digital Banking Facilities: With Reference to Guwahati in Kamrup (Metro) District of Assam. Journal of Management, 5(1), 2018, pp. 6-13 
[4] Grui Anton, "The Impact of Internet Banking on the use of Banking Services", Dissertation, Kyiv School of Economics, Ukraine, 2014

[5] Umbas Krisnanto, Digital banking Made Transaction More Trusted And Secured?, International Journal of Civil Engineering and Technology, 9(11), 2018, pp. 395-407.

[6] Isaeva et al, "Development of the Ukrainian Market of Financial Services on the Basis of Electronic Technologies", Business Inform, 7, 2012, p.124-126

[7] Lauri Piirainen, "Digitalization of the Financial sector and Change management - Case company: Bank X's Digitalization and Change management", Dissertation, Oulu University of Applied Sciences, 2017 